\title{
FORMATION MODEL FOR UNIVERSITY TEACHERS' MONITORING SKILLS
}

\author{
MODELO DE FORMAÇÃO PARA HABILIDADES DE MONITORAMENTO DE \\ PROFESSORES UNIVERSITÁRIOS
}

\author{
MODELO DE FORMACIÓN PARA LAS HABILIDADES DE SEGUIMIENTO DE \\ PROFESORES UNIVERSITARIOS
}

\author{
Guzaliya Zh. FAKRUTDINOVA ${ }^{1}$ \\ Gulzamira D. BAUBEKOVA ${ }^{2}$ \\ Nazilya M. IRGEBAEVA ${ }^{3}$ \\ Bulat I. FAKHRUTDINOV ${ }^{4}$ \\ Oksana V. YUREVA ${ }^{5}$ \\ Svetlana E. NIKITINA ${ }^{6}$
}

\begin{abstract}
The problem relevance that we are studying is attributable to the need to create educational process monitoring at universities and the insufficient development of theoretical, scientific and methodological features of forming teachers' monitoring skills in the course of their educational activities. The major aim of the study is to build a model for the formation of teachers' monitoring skills of and its implementation into the universities' educational process in Kazakhstan. The research methods include modeling which will allow to study this issue as a process of meaningful acquisition of university monitoring skills by teachers. The research results in this article represent a model for the formation of university teachers' monitoring skills, show the properties of monitoring skills; develop a mechanism for introducing this model into practice. The practical significance of this article is that the model is aimed at adapting teachers to modern circumstances of professional activity in the educational sphere and is concentrated upon developing scientific and methodological support for education quality monitoring.
\end{abstract}

KEYWORDS: Model. Education quality monitoring. Monitoring activities. Monitoring skills. Education process.

1 Kazan Federal University, Kazan - Russia. ORCID: https://orcid.org/0000-0002-3416-5300. E-mail: gdautova@mail.ru

2 Turan-Astana University, Nur-Sultan - Kazakhstan. ORCID: https://orcid.org/0000-0002-9454-7191. Email: zamira_baubekova@mail.ru

3 Turan-Astana University, Nur-Sultan - Kazakhstan ORCID: https://orcid.org/0000-0002-6502-6856. Email: n.irgebaeva@mail.ru

4 Kazan Federal University, Kazan - Russia. ORCID: https://orcid.org/0000-0001-5164-4437. Email:bulat_fbi@mail.ru

5 Kazan ${ }^{-}$Federal University, Kazan - Russia. ORCID: https://orcid.org/0000-0003-2946-3423. Email oksanavladi@mail.ru

6 Kazan Federal University, Kazan - Russia. ORCID: https://orcid.org/0000-0003-2325-5447. Email: svetlananik2011@yandex.ru

RPGE- Revista on line de Política e Gestão Educacional, Araraquara, v. 25, n. esp. 6, p. 3459-3471, Dec. 2021. e-ISSN: 1519-9029 
RESUMO: A relevância do problema que estudamos pode ser atribuída à necessidade de desenvolver o acompanhamento do processo educativo nas universidades e ao insuficiente desenvolvimento dos aspectos teóricos, científicos e metodológicos da formação do acompanhamento docente no curso de sua formação. O objetivo do estudo é desenvolver um modelo para a formação de habilidades de monitoramento de professores e sua implementação no processo educacional de universidades no Cazaquistão. Os métodos de pesquisa incluem modelagem que permitirá estudar este problema como um processo de aquisição proposital de habilidades de monitoramento universitário pelos professores. Os resultados da pesquisa neste artigo representam um modelo para a formação de competências de monitoramento de professores universitários, mostram as propriedades de competências de monitoramento; desenvolver um mecanismo para introduzir este modelo na prática. O significado prático deste artigo é que o modelo visa a adaptação dos professores às novas condições de atuação profissional no campo da educação e está focado no desenvolvimento de suportes científicos e metodológicos para o monitoramento da qualidade da educação.

PALAVRAS-CHAVE: Modelo. Monitoramento da qualidade da educação. Monitoramento das atividades. Monitoramento de competências. Processo educacional.

RESUMEN: La relevancia del problema que estamos estudiando es atribuible a la necesidad de desarrollar el seguimiento del proceso educativo en las universidades y al insuficiente desarrollo de los aspectos teóricos, científicos y metodológicos de la formación de las habilidades de seguimiento de los docentes en el transcurso de su formación. El propósito del estudio es desarrollar un modelo para la formación de las habilidades de seguimiento de los maestros y su implementación en el proceso educativo de las universidades de Kazajstán. Los métodos de investigación incluyen modelos que permitirán estudiar este problema como un proceso de adquisición intencionada de habilidades de monitoreo universitario por parte de los profesores. Los resultados de la investigación en este artículo representan un modelo para la formación de las habilidades de monitoreo de los docentes universitarios, muestran las propiedades de las habilidades de monitoreo; Desarrollar un mecanismo para la puesta en práctica de este modelo. La trascendencia práctica de este artículo radica en que el modelo está orientado a la adaptación del profesorado a las nuevas condiciones de la actividad profesional en el ámbito educativo y se centra en el desarrollo de soportes científicos y metodológicos para el seguimiento de la calidad educativa.

PALABRAS CLAVE: Modelo. Seguimiento de la calidad de la educación. Actividades de seguimiento. Habilidades de seguimiento. Proceso educativo.

\section{Introduction}

For effective management of the educational process, it is necessary to constantly monitor both the quality of the educational results of the educational process and the conditions in which it occurs. The ability to monitor the quality of the educational process should be developed at a higher educational institution and improved in postgraduate education in the course of adequately structured content and forms of professional activity (BOLOTIN; SOROKIN, 2009). A new portrait of the teacher is being formed in the educational process: 
now he is not only a teacher, actor and screenwriter, but also a researcher, manager of education and self-education ready to quickly adapt to changes, be open to subjectively new conditions (KHOVANSKAYA; FAKHRUTDINOVA; MAKLAKOVA, 2017). The tasks and content of the pedagogical activity of the modern teacher are changing. In the teacher's work there are new areas that more and more distinctly emerge and meet the requirements of the modern educational process. These areas include pedagogical modeling, pedagogical design, pedagogical management, pedagogical monitoring etc.

Modern realities in the system of education require theoretical comprehension and identification of pedagogical conditions that could ensure the development of teachers' monitoring skills in the process of professional education and practical pedagogical activity (ATANASYAN, 2009; FAKHRUTDINOVA; MENDELSON; ABUTALIPOVA, 2019). The analysis of the pedagogical activity of teachers at particular universities in Kazakhstan indicates that solely a few are able to competently monitor the educational process's outcomes, discover the circumstances and devices of its thriving implementation, assess the degree and efficiency of its application, recognize obstacles and challenges, and make proper modifications.

\section{Materials and Methods}

\section{Research methods}

In the research the applied are as follows: theoretical methods (method of analogies; analysis; synthesis; generalization; concretization; modeling); diagnostic methods (interviewing, testing, questioning); experimental (stating, formative, control experiments); mathematical statistics methods.

\section{Experimental foundation}

The experimental base for the research is S. Seifullin Kazakh Agro Technical University, Turan-Astana University, Nur-Sultan, Kazakhstan. 


\section{Results}

\section{The model's structure}

The analysis of psychological and pedagogical literature gives reason to conclude that management at university is a complex multi-level system, which represents the movement of information between the managing and managed subsystems and its adequate processing when it moves through them. Management is aimed at achieving a high-quality result of activities. Some authors in their works of (KHOVANSKAYA; FAKHRUTDINOVA; MAKLAKOVA, 2017; MAYOROV, 1998; CLARIN, 2004) note that monitoring in the education system is implemented as a comprehensive, dynamic and analytical tracking of processes that determine quantitative and qualitative changes.

Based on the data obtained as the result of the psychological and pedagogical literature analysis, in our study we adhere to the following definition of monitoring: monitoring is a specific form of organization, collection, storage, processing, analysis and dissemination of information about the pedagogical system activities, which provides continuous monitoring of its condition and predicting the ways of its development.

The development of the monitoring skills of university teachers can be carried out in several areas:

- efficiency and effectiveness of intra-university management;

- state, effectiveness and efficiency of innovative work at a higher educational institution;

- state and effectiveness of scientific and methodological work;

- teaching quality state and learning process organization state;

- state of educational work;

- physical education and students physical health;

- degree of development and state of progress, quality of knowledge and skills;

- analysis of final results of the university functioning.

In this regard, education quality monitoring is observation, assessment, and educational proficiency prediction in the educational system.

For performing the experiment, we have designed a scale of the following levels:

1) advanced - $95-100 \%$ of those evaluated cope with the task;

2) medium - $75-95 \%$ of those evaluated cope with the task;

3) low - $55-75 \%$ of those evaluated cope with the task;

4) very low - less than $55 \%$ of those evaluated cope with the task. 
When analyzing the diagnostic work, we used study levels that allow us to judge the results of activities more clearly and specifically. The results of diagnostic works should be presented specifically and clearly so that they can be carefully analyzed and evaluated. The most specific and objective picture was given by the result shown in the matrices "Diagnostic checklist" and "Diagnostic work error analysis" developed by S.V. Kudryavtseva and G.L. Serova.

Just as in the analysis of the group diagnostic work results, it is advisable to present university comparative results graphically, as this will allow a more specific view of the problem. The Prorector for educational work uses the results of the error analysis conducted by the deans of the faculties, summarizes them for all students in the same year, receives a general objective picture of the errors typology, how frequent and widespread these errors are. This serves as the basis for organizing educational and methodical work of the departments, the subject methodological association, individual work with each teacher.

Thus, participating in monitoring, the teaching staff is involved in serious research, which makes it possible to use the data for building a different educational process strategy aimed at obtaining the planned result. Monitoring, which is the basis for making decisions on maintaining or revising any method of action or behavior, becomes the area of decision-making itself. In this case, it is necessary to consider a number of principles for organizing pedagogical monitoring: the principle of conceptuality, the principle of consistency, the principle of duality, the principle of openness etc.

Based on these principles, we have developed a model for the teachers monitoring skills development process. The model contains such structural components as motivation-target, content-procedural, result-evaluating components. The motivation-target component of the monitoring skills development model provides for the formation of a motivation-value, personal attitude to acquisition of the monitoring skills complex, teachers' awareness of the importance of education quality monitoring, emotional personal acceptance of such a professional position when monitoring will become an integral, compulsory component of their professional activity. The content-procedural component of the model involves the formation of teachers' psychological and pedagogical knowledge, gradual acquisition of a set of monitoring skills. The result-evaluating component involves the analysis of results, correction, identification of monitoring skills competence levels based on the selected criteria and indicators. 
Figure 1 - Model for development of educational institution teachers' monitoring skills

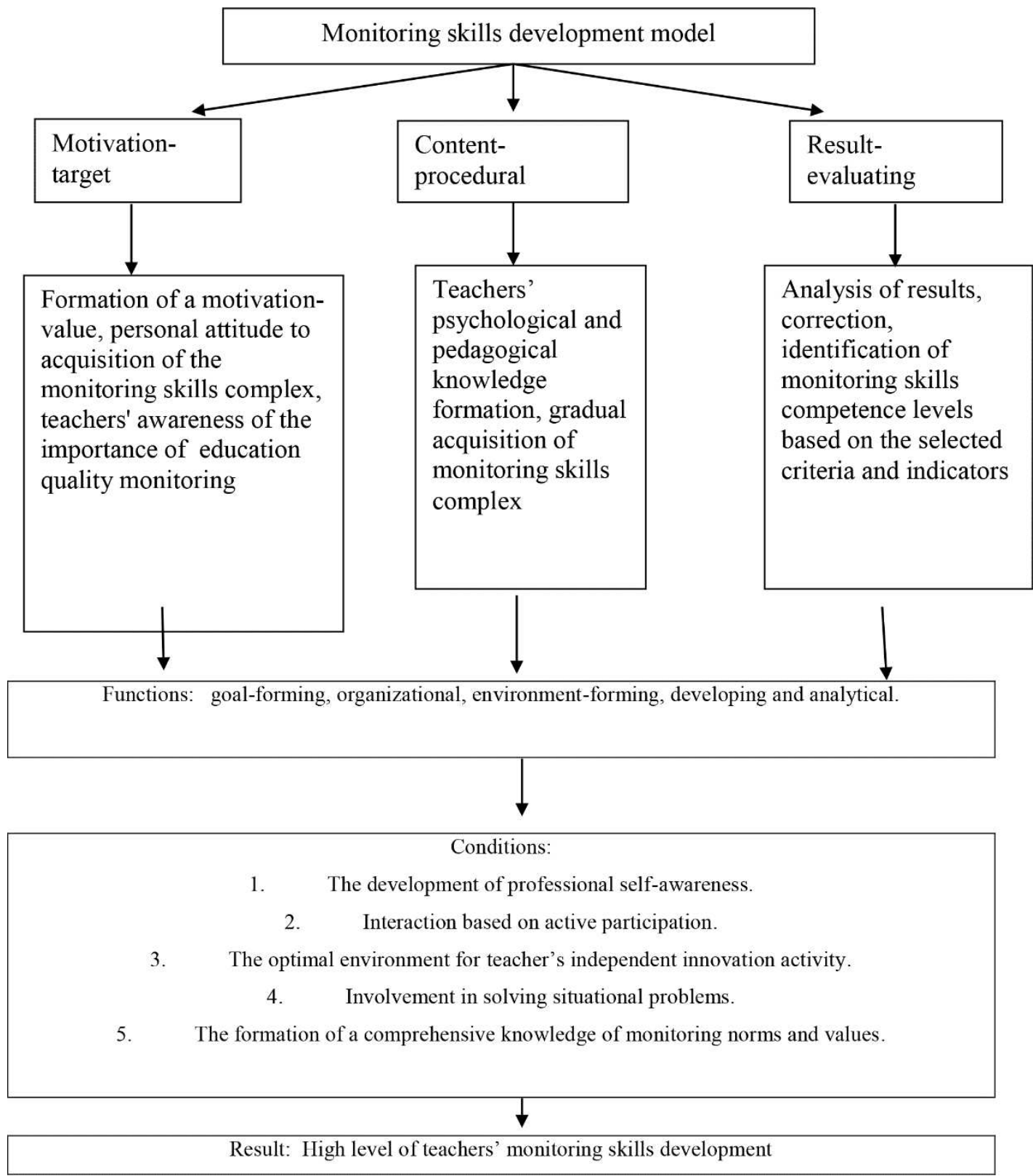

Source: Devised by the authors

The interaction of these components of the model demonstrates the organization of the teachers' monitoring skills process development. The result of the functioning of this model is understood as a certain level of proficiency in teachers' monitoring skills.

This model is the basis for the formation of educational institution teachers' monitoring skills in the context of their real pedagogical activity, which is especially important in the conditions of education modernization. 


\section{Stages of model implementation}

\section{Fact-finding stage}

A total of 75 teachers were surveyed in the research. Analysis of the diagnostic examination results led to the conclusion that most teachers have a low (67.9\%) and medium $(23.5 \%)$ level of monitoring skills development (Figure 2).

Figure 2 - Teachers' monitoring skills proficiency at the fact-finding stage

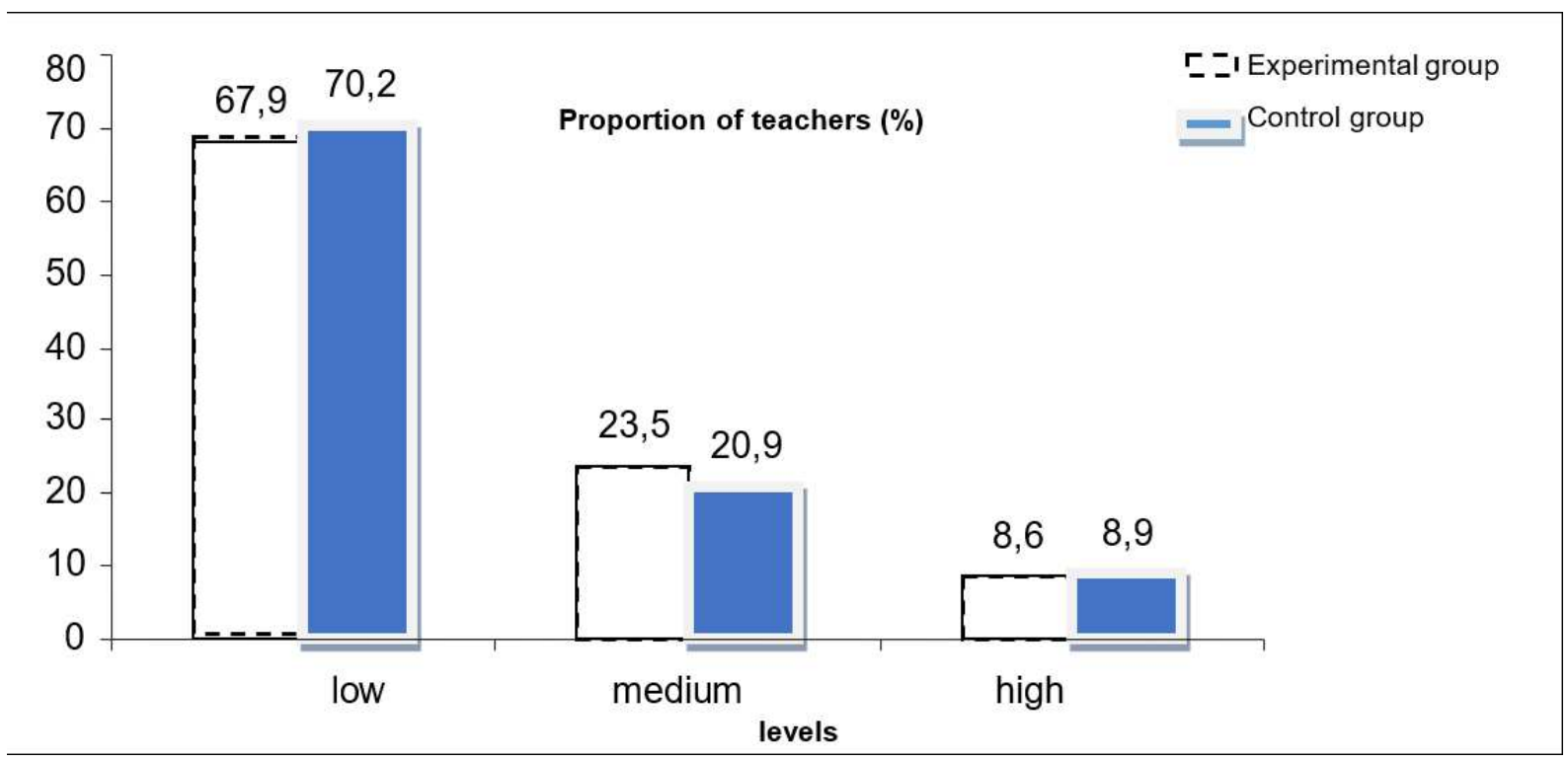

Source: Devised by the authors

Low indicators identified in the motivation-value criterion consisted in insufficient motivation to monitor the education process quality, a lack of understanding the goals and objectives of monitoring, its significance, lack of need to build professional activities based on the results of monitoring.

Over the course of the educational process study, we have found shortcomings in the work of the methodological service with teachers on the formation of monitoring skills associated with the predominance of passive working methods that do not allow building their own educational trajectories. Assessment of students' activities is subjective on the part of the teacher and often does not correspond with students' self-assessment. 


\section{Developing stage}

Implementing pedagogical circumstances in the process of the forming experiment required involving teachers into interactive cooperation with other teachers and the methodological service in order to create their own educational trajectories in the course of the methodological work. Based on implementing a stage-by-stage pedagogical interaction algorithm, teachers selected an educational path of a particular orientation (developmental and creative orientation, and adaptive type) relying upon the level of the monitoring skills proficiency (GAYAZOV, 2003). Together with the methodological service, we have developed and tested an educational program for teachers called "Monitoring the quality of education" was developed and tested. During the implementation of this program teachers participated in project activities, constructive meetings, round tables, presentation workshops, brainstorm events, problem solving workshops, business games and roleplaying, education quality monitoring discussions, trainings, which encouraged not only the exchange of knowledge, but also meanings and values among teachers, experience, improvement and intensification of knowledge, understanding material on education quality monitoring by teachers. The educational program was implemented in the ambiance of friendliness and reciprocal interaction, which helped develop teachers' cognitive activity, converting it into greater forms of collaboration and interaction.

The purposeful formation of teachers' monitoring skills in the experimental group was ensured through the implementation of stage-by-stage monitoring of a particular subject educational classes where the joint monitoring activities of the teacher and student ensured the evolution of their monitoring skills. Stage-by-stage monitoring involved diagnostics, analysis of educational classes stages implementation success and timely correction of all structural components of an educational class. Pedagogical activity in the educational class monitoring mode allowed implementing a qualitative approach to the organization of the educational process. The effectiveness of an educational class was ensured by the high-quality implementation of each of its stages, which was monitored, diagnosed, predicted and timely corrected. 


\section{Control stage}

At this stage of the experiment, diagnostic assessments were carried out using the same methods as at the fact-finding stage of the experiment in order to determine the dynamics and level of teachers' monitoring abilities proficiency during the experimental work. The control assessment data revealed shifts in comparison with measurements of a fact-finding experiment by all the standards. Nonetheless, these shifts were significant merely in the experimental group where there was an alteration in the teachers' number with medium $(59.4 \%)$ and high $(31.3 \%)$ levels of monitoring skills.

The changes that occurred during the experimental examination enabled us to pursue the overall dynamics of teachers' monitoring skills formation. Based on the forming influence, significant changes took place in such monitoring skills formation criteria as motivation-value, cognitive and operational-activity-related criteria. Teachers were reoriented towards understanding the values and ideas of monitoring activities from the point of view of its educational and social significance, they started having a desire to design pedagogical activity regarding the monitoring component. Changes in the cognitive sphere manifested themselves in the systematization of knowledge and ideas about the quality of education and pedagogical monitoring. In their statements teachers pointed out the special relevance of monitoring knowledge. Most teachers correctly developed a plan for monitoring study of the pedagogical phenomenon, developed and adapted diagnostic tools, collected data and interpreted them, developed a characteristic of monitoring skills formation levels, correlated the obtained data with the norms, formulated a pedagogical diagnosis. The final diagnostic assessment was summative and made it possible to judge the degree of teachers' monitoring skills formation. The findings of this assessment suggest that because of the experimental study, most teachers (31.3\%) who took part in this work had a high level of monitoring skills after its completion and $59.4 \%$ of teachers had a medium level. An analysis of the monitoring skills formation dynamics in the experimental group gives reason to believe that the implementation of the developed model makes it possible to increase the efficiency of the teachers' monitoring skills formation process significantly. 


\section{Discussions}

Given the literature analysis, it is necessary to state the fact that there are no special studies on the problem of the university teachers' monitoring skills formation. At the same time, the formation of the teacher's general pedagogical skills and their different groups is carefully studied in the studies of O. A. Abdullina, A.V. Usova (ABDULLINA, 1998; USOVA, 1987). In their works, E. Khovanstaya, A. Fakhrutdinova, V. A. Kalney, S. E. Shishova (KHOVANSKAYA; FAKHRUTDINOVA; MAKLAKOVA, 2017; KALNEY; SHISHOV, 1999). The primary stages of its implementation upgraded means for tracking the progress and results of the educational process, improvement conditions, the possibility of using data technologies in monitoring organization and monitoring classification by various criteria. A typology of monitoring by the control systems hierarchy level is studied by A. N. Mayorov (MAYOROV, 1998). Such pedagogical conditions as the involvement of teachers into interactive cooperation to create their own educational trajectories during the methodological work, where the joint monitoring activity of the teacher and student ensured the co-evolution of the teacher's and student's monitoring skills, contribute to the formation of teachers' monitoring skills (BARINOVA; KARUNAS, 2015).

Interactive cooperation changes the position of the methodologist teacher (or methodological service) and other teachers: the activity of the methodologist teacher (or methodological service) gives way to the activity of other teachers, whereas the task of the methodologist teacher (or methodological service) is to facilitate the manifestation of other teachers' initiatives.

The methodologist teacher (or methodological service) refuses to play the role of a filter that passes information through itself and performs the function of an assistant in the work. Interactive cooperation is widely used in intensive learning. Interactive cooperation methods include those that facilitate the involvement of cooperation participants in the active process of obtaining and processing information.

Interactive cooperation of some teachers with other teachers and the methodological service helps to build individual teachers' educational trajectories to develop monitoring skills.

Acquiring timely data over the course of the educational process permits making quick corrections in case some deviations occur. Thus, stage-by-stage monitoring of a subject educational class facilitates timely intervening in patterns of the educational process, the mechanisms, or personality growth (BARINOVA; KARIMOVA, 2014). 
One of the conditions for the educational process monitoring at the subject level is organizing and conducting students' unsupervised activity. During the educational process stage-by-stage monitoring at the subject level, a joint monitoring action of the students and teacher is applied, providing a parallel evolution of the teacher and students' monitoring skills, which results in the creation of proper self-assessment through self-analysis.

Theoretical analysis and educational institutions' experience in teachers' professional activities improvement showed that with the appropriate work of methodological services, it is possible to successfully develop teachers' abilities to monitor the quality of the educational process.

\section{Conclusion}

The formation of teachers' monitoring skills in the process of pedagogical activity will be successful if the development of the teacher's pedagogical activity is organized as a process of purposeful and conscious acquisition of skills by specialists to monitor the quality of education based on the improved functional and structural model, consisting of interrelated motivation-target, content-procedural and result evaluating components (MIKHAILOV; YURIEVA; MIASNIKOV, 2018).

A modern university teacher should be able to describe, explain and predict his activities in the market of intellectual developments (FAKHRUTDINOVA; SHAMSUTDINOVA; RAMSIYA, 2019).

The main factor ensuring the effectiveness of the teacher in the field of innovation and commercial activity is his readiness for this work, which consists in the ability to respond to changes quickly and adequately in the market of scientific and educational services.

This article's materials can be beneficial for teachers who are integrating to new situations of professional activity in the education sphere, and for everyone who is interested in the problems of higher education.

ACKNOWLEDGEMENTS: This study is carried out based on the Russian Government Program of Competitive Growth of Kazan Federal University. 


\section{REFERENCES}

ABDUllinA, O. A. Monitoring of the training quality. Higher Education in Russia, v. 3, p. 40-46, 1998.

ATANASYAN, S. L. Features of assessing the quality of student training in the context of comprehensive informatisation of a pedagogical university. Standards and Monitoring in Education, v. 4, p. 58-62, 2009.

BARINOVA, N. A.; KARIMOVA, N. KH. Monitoring of distance learning on the subject. Historical and socio-educational thought, v. 6, n. 28, p. 300-302, 2014.

BARINOVA, N. A.; KARUNAS, E. V. Designing an individual training program as a condition for the implementation of Federal State Education Standards. Kazan Pedagogical Journal, v. 3, n. 110, p. 70-75, 2015.

BOLOTIN, I. S.; SOROKIN, I.S. Problems of the education quality in the context of innovative economy. Social and Humanitarian Knowledge, v. 5, p. 172-180, 2009.

CLARIN, M. V. Pedagogical technology in the educational process: analysis of foreign experience. Moscow: Znaniye, 2004. 145 p.

FAKHRUTDINOVA A. V.; MENDELSON V. A. ABUTALIPOVA L. N. Competence Development For The Competitive Specialist Education. Revista San Gregorio, v. 34, p. 3946, 2019.

FAKHRUTDINOVA, A. V.; SHAMSUTDINOVA, D. V.; RAMSIYA, N. G. Paradigmatic methodology of civic culture formation process in young generation. Journal of Sociology and Social Anthropology, v. 10, n. 4, p. 198-202, 2019.

GAYAZOV, A. S. Education and educatedness of a citizen in the modern world. Moscow: Nauka. 2003. 373 p.

KALNEY, V. A.; SHISHOV, S. E. Technology for monitoring the quality of education in the "teacher - student" system. Moscow: Pedagogical Society of Russia, 1999. 275 p.

KHOVANSKAYA, E. S; FAKHRUTDINOVA, A. V; MAKLAKOVA, N. V. University as a social phenomenon. Man in India, v. 97, n. 9, p. 101-107, 2017.

MAYOROV, A. N. Monitoring in education. St. Petersburg: Education - Culture, 1998. 428 p.

MIKHAILOV, F. B.; YURIEVA, O. V.; MIASNIKOV, D. A. Strategies of the human capital development in conditions of accelerating diffusion of technical innovation under influence processes of globalization. In: Globalization and Its Socio-Economic Consequences, 18th International Scientific Conference, PTS I-VI, University of Zilina, Slovakia, 2018. p. 2236-2243.

USOVA, A. V. The formation of student learning skills. Moscow: Znaniye. 1987. 263 p. 


\section{How to reference this article}

FAKRUTDINOVA, G. Zh.; BAUBEKOVA, G. D.; IRGEBAEVA, N. M.; FAKHRUTDINOV, B. I.; YUREVA, O. V.; NIKITINA, S. E. Formation model for university teachers' monitoring skills. Revista on line de Política e Gestão Educacional, Araraquara, v. 25, n. esp. 6, p. 3459-3471, Dec. 2021. e-ISSN:1519-9029. DOI: https://doi.org/10.22633/rpge.v25iesp.6.16099

Submitted: 11/04/2021

Required revisions: 22/08/2021

Approved: $25 / 11 / 2021$

Published: $30 / 12 / 2021$

Processing and publication by the Editora Ibero-Americana de Educação. Correction, formatting, standardization and translation.

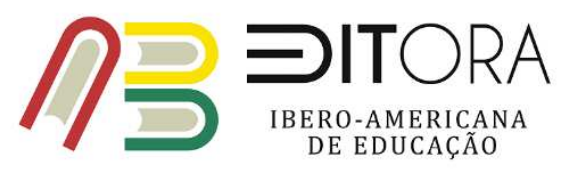

